\title{
KODÁLY MUSIC INSTRUCTIONAL PRINCIPLES IN GHANAIAN BASIC SCHOOLS: A CONTEMPLATION ON ADAPTATION
}

\author{
Samuel Agbenyo ${ }^{1}$, Augusta Arko-Mensah ${ }^{2}$ and Michael Anthony Kwesi Adomina ${ }^{2}$ \\ ${ }^{1}$ Department of Music, University of Mississippi, Oxford, USA \\ ${ }^{2}$ Department of Music Education, University of Education, Winneba, Ghana
}

Cite this article:

Samuel A., Augusta A., Michael A.K.A. (2022), Kodály Music Instructional Principles in Ghanaian Basic Schools: A Contemplation on Adaptation. Journal of Advanced Research and Multidisciplinary Studies 2(1), 9-17. DOI: 10.52589/JARMSMRVEBKHK

\section{Manuscript History}

Received: 26 Jan 2022

Accepted: 5 Feb 2022

Published: 22 Feb 2022

Copyright $@ 2022$ The Author(s). This is an Open Access article distributed under the terms of Creative Commons Attribution-NonCommercialNoDerivatives 4.0 International (CC BY-NC-ND 4.0), which permits anyone to share, use, reproduce and redistribute in any medium, provided the original author and source are credited.
ABSTRACT: This multiple case study sought to find out the nature and principles of Kodàly music education, and draw inferences on its adaptability to the Ghanaian context. Using a semi-structured interview, data were collected from three OAKE members, analyzed with the aid of Nvivo 12 pro software, and reported in an intermingled narrative-descriptive manner. Findings revealed that the Kodàly approach, which traces its root to Budapest in Hungary, is a fruitful choice for music instruction. Zoltán Kodály (1882-1967), an educator and a philosopher, is credited with this pedagogical exploit. Diverse materials, tools and techniques have been identified in relation to the principles, with instances of contextual adaptations in different countries. We recommended that the Kodàly approach be adopted and adapted to Ghanaian basic school music curriculum. Future research will examine specific areas of adaptability in terms of contextual distinctiveness at various levels of education in Ghana.

KEYWORDS: Kodály, Hungary, Principles, Folk Songs, Ghana, Curriculum, Adaptation. 


\section{INTRODUCTION}

The Kodaly principles refer to a philosophy of education and a concept of teaching, which owes its pioneering credit to Zoltán Kodály (1882-1967), an illustrious visionary Hungarian composer, educator, and philosopher. His work has influenced musicians and music educators around the world. Following his folk song collecting trips with Béla Bartók in Hungary in the early 1900s, Kodály conceived of a monumental idea that music could be taught artistically using the traditional folk songs of one's own culture. The Kodàly approach thus provides a philosophically inherent framework within which this paper unfolds.

The priority element of the Kodály approach to music instruction is singing. Sandor (1966) confirmed this when he said, "if we attempt expressing the essence of education in just one word, it can only be singing..." adding that "...it is a long-accepted truth that singing provides the best start to music education" (p. 201). The philosophy has it that music education should begin with learning to love music as human sound and as an experience that enriches life. This is because the voice is the most natural instrument and one which every person possesses. For that matter Kodály referred to singing as "the essence" of this concept. He noted that what we produce by ourselves is better learned, and there is a stronger feeling of success and accomplishment. The principal stresses that learning through singing should precede instrumental training since it is in the child's best interest to understand the basics of reading music before beginning the difficult task of learning the technique of an instrument.

A vital feature of the Kodály approach is sequencing. Presentation of materials, concepts, and development of skills can be done in a meaningful way only if the curriculum is well sequenced. A carefully planned curricular sequence-well taught-will result in successful experiences for children and teachers. Success breeds success and fosters the love of music. A Kodály sequenced curriculum is an experience-based approach to learning rather than a mechanical cognitive developmental approach. "Music must not be approached from its intellectual, rational side, nor should it be conveyed to the child as a system of algebraic symbols, or as a secret writing of a language with which he has no connection. The way should be paved for direct intuition." (Selected Writings, p. 120). Hence, the Holy Names University Kodály Center for Music Education developed

"Sequence of Introducing Music Concepts/Elements" which offers a suggested order for introducing music elements and concepts when starting in first grade. Grade guidelines are based on two or more music classes per week. This sequence has been utilized in the United States over the past four decades, seeking to implement Kodály's ideas in music education.

Details of the sequence are delineated as follows:

Grade 1: Ta ti-ti, 2-meter rhythmic form/icons, so-mi, la, quarter rest, form: repeat do.

Grade 2: Re, half note, do pentatonic scale, form: AA, AB, AABA, etc., question and answer, form: 1st and 2nd endings (A, Av), 4 meter, low la, syncopation. low so, la pentatonic scale, whole note; half and whole rest.

Grade 3: Dotted half note (in 4 meter), anacrusis, eighth note/eighth rest, so pentatonic, high do absolute (letter) names, re pentatonic, rhythms within 6/8-meter, 6/8-meter, fa, do pentachord scale whole and half step, lowered letter name $(\mathrm{Bb})$, tiri-tiri, do hexachord scale, titiri, tiri-ti. 
Grade 4: Ti diatonic (major) scale, do rename whole/half steps: M2, m2, tam-ti, ti-tam, sequence intervals: $\mathrm{M} 3, \mathrm{~m} 3,3$ meter, cut time, la pentachord scale, raised letter name (F\#), la hexachord scale diatonic (minor) scale-la. Key signatures: $\mathrm{C}$ major and a minor, melodic sequence, tim-ri, ri-tim. Key signatures: $F$ major and d minor, $G$ major and e minor.

Grade 5: Parallel thirds. Key signatures: D major and b minor. Intervals: fourths, augmentation/diminution, fifths, parallel fifths, horn call key signatures: Bb major and g minor, harmony: tonic/dominant altered notes: si harmonic minor scale, (classical period materials for this level).

Grade 6: key signatures: Eb major and c minor. Interval: sixths. Mode: dorian. Altered note: fi/fe, melodic minor scale. Key signatures: A major and f\# minor. Interval: sevenths. Harmony: subdominant. Mode: mixolydian, and altered note: ta/taw, (medieval/renaissance materials for this level).

The need to premise music education on the native musical culture is "inveterate in music scholarship and firmly established ipso facto" (Debrah, 2019, p. 13). Furthermore, Kalinde and Vermeulen (2016) observed that music educators have generally identified music of children's indigenous culture as key in laying a foundation for music education. It is through this folk music that language and the skills and concepts necessary for developing music literacy are best taught. This argument corroborates the proven effectiveness of learning that evolves from the known to the unknown as embedded in developmental psychology as well as the stage-andphase theories (Debrah, 2019).

Contrarily, research indicates that less than 27 per cent of people in South Africa listen to music of African origin. (Herbst \& Rijsdijk, 2005). In Ghana, traditional musical forms have gradually become occasional, performed only during festivals or special events. As large as 87 per cent of the Ghanaian people have shown affinity for musical genres such as gospel, highlife/hip-hop, rhythm \& blues, and rock ballads while only 13 per cent show preference for classical and folk music. The problematic nature of this circumstance is explicated in Akono's (2003) postulation that familiarity with one's own folk music is a prerequisite for the development of culture-relevant knowledge as well as cultural identity. Corroborating this argument, Okafor (1991) avowed: By means of song texts, "a person learned the moral codes of his land, its chronology and history, and the guiding principles and ethics of his land. He also learned about his own language, the things his people lived by, and how society worked" (p. 60).

The purpose of this paper was to find out the nature and principles of Kodàly music education, and draw inferences on its adaptability to the Ghanaian context. The study was guided by four research questions as follows: 1) How did the Kodàly music education originate? 2) What are the principles and tools of Kodàly music education? 3) How relevant is Kodàly music education to the Ghanaian context? And 4) How adaptable is the Kodàly approach to the Ghanaian context? 


\section{METHOD}

This study was a qualitative multiple case study in which participants $(N=3)$ namely Pamela, Ricky, and Ronny (pseudonyms) were purposively selected from the Organization of American Kodàly Music Educators (OAKE) and interviewed. Access to the participants was gained through the OAKE Facebook page, where consent of each participant was sought to participate in the study. The OAKE Facebook page serves as a vital platform for registered experts in Kodàly Music Educators. All three participants had had both the traditional music education and level III training in the Kodàly way of music instruction. So, they were in position to tell differences between the two approaches. By means of a semi-structured interview protocol, individual interviews were held via zoom cloud meeting on September 22, 26, and 27 with Ricky, Pamela, and Ronny respectively.

The first interview session lasted for 52 minutes with Ricky, followed by 48 minutes with Pamela and finally, 41 minutes with Ronny. After each interview session, we (researchers) labelled the recordings and memos and ended the session with debriefing. Each recording was subsequently transcribed and analyzed thematically using the Key Word in Context (KWIC) technique in Thelwal's (2021) Word Association Thematic Analysis. Findings were then presented mainly in a narrative-descriptive style, with indications of relevant corroborations deemed needful.

\section{FINDINGS AND DISCUSSIONS}

According to Choksy (1998), this idea resulted from Kodály's observation that students matriculating in "Zeneakedemia", also known as Franz Liszt Academy of Music, the highest music school in Hungary, had an appalling level of music illiteracy. "Not only were these students unable to read and write music fluently but in addition, they were totally ignorant of their own musical heritage" (Choksy, 1998, p. 1). Therefore, Kodály took it upon himself as a mission to educate both students in the academy and the entire Hungarian populace, teaching them their own music and elevating the level of music literacy among the Hungarian folks.

Gathering talented, creative teachers around him, Kodály developed a philosophy of music education based on the radical idea of universal music literacy. The Kodály approach is a comprehensive program to train learners in basic musical skills and teach the reading and writing of music, which involves an integration of many of the best ideas, techniques, and approaches to music education. It is an organic, experience-based approach to music teaching and learning (oake.org, retrieved October 19, 2020).

Principles of the Kodály approach include strong emphasis on the use of folk songs and games of the learner's native culture such as traditional children's songs and games, and then folk songs of other cultures, music of the masters from all ages as well as pedagogical exercises written by master composers. Folk songs are also referred to as "old songs" (Alan Spurgeon, Personal Communication, October 14, 2020). "If we ourselves sing often, this provides a deep experience of happiness in music through which we learn to know the pulsation, rhythm, and shape of melody. Folk songs are meant to be sung; they are not meant to be read" (Tinka, 1987, p. 138). The enjoyment derived from singing folk songs further encourages the study of instruments and listening to other pieces of music as well (Kodály, 1964). 
Folk music is the music of the people. There can be no better material for singing than the native songs and games used by children for centuries. Folk music has all the basic characteristics needed to teach the foundations of music and to develop the needed love of music-love that will last a lifetime. Folk music is the classical music of the people, and as such, is a perfect bridge leading to and working hand-in-hand with art music. "The compositions of every country, if original, are based on the songs of its own people. That is why their folk songs must be constantly sung, observed, and studied." (Kodály, 1964 in Selected Writings, p. 120). The Kodály way of music learning requires early start (5 to 7 years old) allowing culture and education to evolve organically with the child. It therefore frowns on late starts and attempts to accelerate learning with policy drives which tend to build culture from above, a top-down approach - one of the greatest deficiencies in music education (Kodaly, 1941 in Selected Writings).

The main tools of the Kodály strategy include the movable-doh system (developed by Sarah Glover and refined by John Curwen), the rhythmic duration syllable (similar to the French Solfège) and the hand signs (generally credited to John Curwen). Solfège is the best tool for developing the inner ear. It is an invaluable aid in building all musical skills: sight singing, dictation, ear training, part hearing, hearing and singing harmony, perceiving form, and developing memory.

The moveable doh system, highly developed in English choral training, was advocated by Kodály as a tool for teaching music literacy. Use of the pentatone (do, re, me, so, la) was recommended by Kodály for early training of children because of its predominance in their folk music. Kodály training is a complete and comprehensive approach to music education (MENC, 1994. The development of all skill areas begins very early with simple tasks required of all the students. As knowledge grows, skills are developed further in a sequential manner. In addition to music reading and writing which are begun at an early stage, the following skill areas are also developed: part-singing, part-hearing, improvisation, intonation, listening, memory, phrasing and understanding of form. An awareness and knowledge of musical styles develops as skills become more proficient. "The good musician understands the music without a score, and understands the score without the music. The ear should not need the eye nor the eye the (outer) ear in order to handle music meaningfully." (Kodály, 1974 in Selected Writings p. 192).

\section{THE KODÁLY APPROACH IN OTHER GEO-CULTURAL CONTEXTS}

Although the Kodály way of music education traces its roots to Budapest, it has transcended the geographical and cultural boundaries of Hungary. Due to the transferable nature of its philosophy, the Kodály approach has been adapted and favorably re-contextualized in several countries and jurisdictions around the world. Dating as early as the 1950s and to date, countries that have successfully embraced this strategy for music education include America, Japan, Canada, Germany, China, Tokyo, Great Britain, Denmark, Iceland, Finland, Israel, Australia, and South Africa, among others (Choksy, 1998, p. 3-8). The popularity of this music instructional approach is explained in what I describe as a greatly demystifying view of Sinor (1986) who stated that: 
What the rest of the world calls the Kodály method is merely the effort in Hungary inspired by Zoltán Kodály to open to children the beauty available to them through the greatest music, folk songs of the domicile culture... any music teaching that strives to attain this goal could, indeed, be called Kodály teaching. In this sense, Leonard Bernstein, Yehudi Menuhin, or Carl Orff might be called Kodaly teachers, but neither they nor Kodály would think it relevant or necessary to do so. In Hungary, no distinction exists between teaching "Kodály" and teaching some other way, because what is being taught is music and not "Kodály". Of course, Zoltán Kodály had a profound influence on the practice of music education in Hungary and subsequently on adaptations of those practices in the rest of the world (p. 37).

The above quote suggests that wherever there is a folk song, there can be joyful music teaching and learning, leading to strong music literacy and personal development. There is hardly a cultural context without music anywhere in the world. Titon et al. $(2009$, p. 1) indicate that music was part of primordial human life and continues to evolve. From antiquity, music has been 'such a pervasive form of human experience that everyone in any society can have some experience with music (Hodges, 2020, p. 317). Thus, every nation (culture) has a heritage of folk songs and for that matter the potential for Kodály music education.

Commenting on the usefulness of the Kodály principles in her non-Hungarian community school, Pamela indicated the importance of singing in music teaching and learning activities: "I see very positive results ever since I took the Kodály levels training program. Singing is a natural thing that all of us must do; so, I love that emphasis of encouraging everyone to sing" ... "it makes me know my process in teaching any given concept: where to start from, what steps to go through and where to end it" (Zoom Interview, September 26, 2020). Furthermore, the Kodály approach broadens the user's horizon on music teaching and learning. It helps the teacher to differentiate their ways of teaching in the sense that they have different ways of teaching the same thing so that learners do not get bored. For instance, by the Kodály approach, the teacher is able to engage the student to think meaningfully about the music by taking time to approach a given song in different ways-at one time they look at the melody the song, at another time they look at the rhythms, then later the dynamics, phrasing, etc. Thus, the same piece is approached differently at different times. That makes the various concepts properly understood by the students and makes them become musically independent.

\section{ADAPTING THE KODÁLY PRINCIPLES IN GHANAIAN BASIC SCHOOLS}

Ghana is a music-making country (Nketia, 1999), and "Ghanaian children are music loving children" who love singing (Flolu \& Amuah, 2003, p. 21). The country abounds in folk musical resources. During Ghana's pre-colonial, colonial, and early post-colonial eras, folk songs constituted a major means of both entertainment and moral education, packaged with folktales (storytelling), usually organized in the evenings (Dzansi-McPalm, 2004; Lipman, 1994). Folk songs have since been an important part of the nation's oral-aural cultural birthright although transmitted with modernization over time. 
The current Creative Arts Curriculum for Ghanaian primary schools, Kindergarten through class six (CRDD, 2000, p. ix) of which "music and dance" is a component, recommend the use of "indigenous music" for instructional activities. Prior to this national awakening in Ghana, Horton (1997) had observed that in Africa and elsewhere, educators had already called for the development and use of educational resource materials on traditional African music as a means of preserving and perpetuating this vital art form through the school system. "This call has become increasingly urgent in recent years as the breakdown in traditional systems of cultural transmission among modernizing nations on the continent of Africa has resulted in much of its traditional music being lost or severely misrepresented" (Horton, 1997, p.1). This concern partly explains the importance of folk music not only as an indispensable instructional asset but also as a means of ensuring our cultural longevity. Several other authors have advocated the need for folk songs in education, with emphasis on children's education (Hess, 2010; Uzoma \& Olayemi, 2020; Feay-Shaw, 2002; McKoy, 1998), with Ibekwe and Ojukwu (2020) describing the approach as the "Africa-sensed music education and creativity" (p. 16).

The role of folk songs in music education as enshrined in the Kodály approach was corroborated by Ronny thus: "If for any reason I am told to change from the Kodály approach and teach music through any other way, I will have to quit music teaching and find a different job somewhere" (Zoom Interview, September 27, 2020). Simply, in his brain, Ronny could not understand any other way of teaching music better without the Kodály approach. He maintains that "folk songs are the most organic materials for teaching music." He had realized that if a music teacher deviates from the Kodály way of teaching, with emphasis on singing folk songs, the children will miss something vital, and they are not going to develop the same way as those taught by the Kodály approach because it is so comprehensive and successoriented.

On his part, Ricky reiterated the philosophy of Kodály, arguing that, "understanding musical concepts is a fundamental human right for every child in the school system; hence, none must be denied." By using the children's own (indigenous/folk songs) to teach them, they will not only be able to sing but they will also be able to listen to music intelligently and write (create) their own musical ideas; "that is what it takes to be human." They can sing in tune, sing in harmony with each other, audiate musical sounds, write out what they hear, and they can create new things from what they have been taught (Zoom Interview, September 22, 2020).

There is adequate emphasis on all aspects of being a musician. It helps learners to know the subject matter that the instructor teaches, and also helps them develop musically with natural meaning. The interviewee contended that people have intimate connection with their own folk songs because the language originates with them. So, it helps best when folk songs are used to teach music. The learners get refined as they grow and transmit the music from one generation to another. Furthermore, people like to share the music with others since the (folk) music is of lasting value to them. 


\section{CONCLUSION}

This paper has attempted to find out the nature and principles of Kodàly music education and draw inferences on its adaptability to the Ghanaian context. Considering the folk music resources and opportunities in Ghana, the adaptation of the principles could give a great boost to the country's pursuit of successful music education. In Ghana, folk songs are already available in good volume to both teachers and learners in the community and the school system while many more could be harnessed through further field research. Ghana, therefore, could be counted as a nation which is very well positioned to benefit from the joyful music instructional experience by adapting the Kodály principles. Beginning from the primary grades, and with context-sensitive application of the foregoing Kodàly principles, there is a prospect of advancing musical knowledge, skills and attitudes through the higher levels of music education in Ghana.

\section{REFERENCES}

Akrofi, E. A. (1982). The status of music education programs in Ghanaian public schools (Doctoral dissertation, University of Illinois at Urbana-Champaign).

Akuno, E. A. (2003). To 'sing the Lord's song in a strange land': Music in the education of the Kenyan child. In Herbst, A. (Ed.). Emerging Solutions for Musical Arts Education in Africa, (54-63). Cape Town: African Minds.

Choksy, L. (1998) The Kodály Method I: Comprehensive Music Education. New Jersey: Prentice Hall.

Curriculum Research and Development Division (CRDD.) of GES. (2000), Teaching Syllabus for Music and Dance (Primary 1-6). Malaysia: B.H.S. Printing Sdn. Bhd.

Dzansi-McPalm, M. P. (2004). Children's playground music as cultural expressions in Ghanaian schools. University of Illinois at Urbana-Champaign.

Feay-Shaw, S. J. (2002). The transmission of Ghanaian music by culture-bearers: From master musician to music teacher. University of Washington.

Flolu, James \& Amuah Isaac. An introduction to music education in Ghana for universities and colleges. Black Mask Limited, 2003.

Herbst, A., de Wet, J., \& Rijsdijk, S. (2005). A survey of music education in the primary schools of South Africa's Cape Peninsula. Journal of Research in Music Education, 53(3), 260-283.

Hess, J. (2010). The sankofa drum and dance ensemble: Motivations for student participation in a school world music ensemble. Research Studies in Music Education, 32(1), 23-42.

Hodges, D. (2020). Music in the human experience: An introduction to music psychology (2nd ed.). Routledge.

Horton, C. D. (1997). Educational resources on traditional African music: An annotated bibliography of contemporary offerings and suggestions for their use in the classroom. Journal of Negro Education, 16-28.

Ibekwe, E., \& Ojukwu, E. (2020). Africa-sensed music education and creativity: Examples of children's folk songs in Igbo culture. Journal of Nigerian Music Education (Jonmed), 11(1), 60-69.

Kodály, Z. (1974). The selected writings of Zoltán Kodály. (L. Halápy \& F. Macnicol, Trans). Boosey \& Hawkes. http://oake.org/aboutus/kodalyphilosophy.aspx) 
Lipman, D. (1994). We all go together. Creative activities for children to use with multicultural Folksongs. Oryx Press, 4041 North Central at Indian School Road, Phoenix, AZ 85012-3397.

McKoy, C. L. (1998). The effect of two instructional approaches on fourth-grade students' preferences for indigenous folk music of Ghana. The University of North Carolina at Greensboro.

Nketia, J. K. (1999). A guide for the preparation of primary school African music teaching manuals. Accra, Ghana: Afram Publications.

Okafor, R. C. (1991). Music in Nigerian Education. Bulletin of the Council for Research in Music Education, 1(108), 59-68.

Otchere, E. D. (2019). Sharing concerns: A direction for African music education. In Akuno (Ed). Music Education in Africa (pp. 59-75). Routledge.

Pamela. Interview with authors. Personal interview. Wisconsin, USA, September 22, 2020.

Ricky. Interview with authors. Personal interview. Nebraska, USA, September 26, 2020.

Ronny. Interview with authors. Personal interview. Oxford, USA, September 27, 2020.

Thelwall, M. (2021). Word association thematic analysis: a social media text exploration strategy. Synthesis Lectures on Information Concepts, Retrieval, and Services, 13(1), 111 .

Titon, J. T. et al. (2009 ed.) [2002]. Worlds of Music: An Introduction to the Music of the World's Peoples (5th edition). New York: Schirmer Books. With 4 accompanying CDs.

Uzoma, I. J., \& Olayemi, I. R. (2020). Documentation of Ebira folksongs: A dynamic innovation towards qualitative childhood education in Kogi State. Journal of the Association of Nigerian Musicologists, 14(1), 306-321.

Vermeulen, D., \& Kalinde, B. (2016). Fostering children's music in the mother tongue in early childhood education: A case study in Zambia. South African Journal of Childhood Education, 6(1), 1-9. 